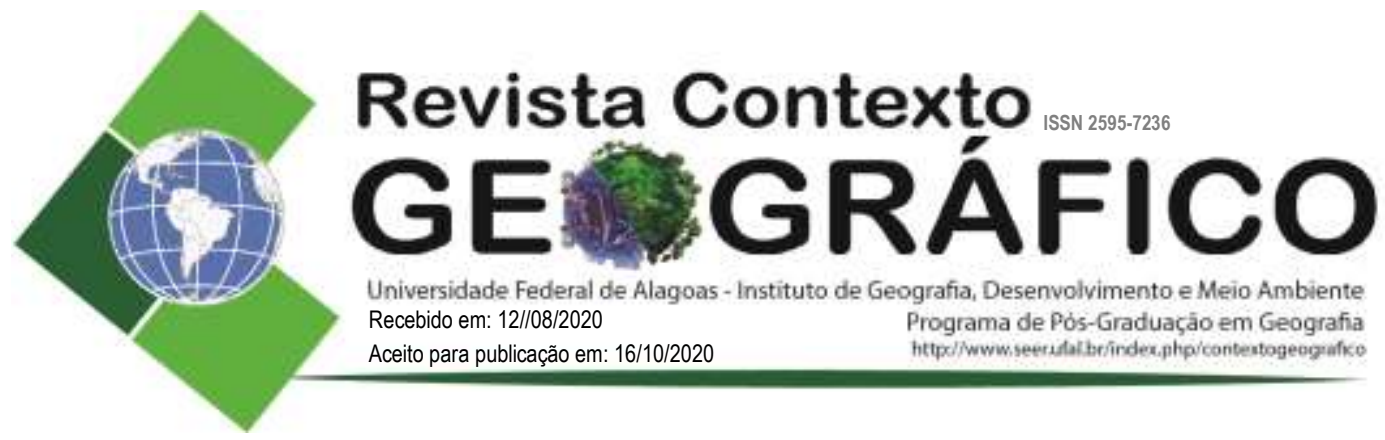

\title{
A GÊNESE DA FRONTEIRA OCIDENTAL DA AMAZÔNIA: AS CIDADES GÊMEAS TABATINGA (BRASIL) E LETICIA (COLÔMBIA)
}

\author{
Emerson Flávio Euzébio \\ Mestre em Geografia Humana pelo Programa de Pós-Graduação em Geografia da Universidade \\ de São Paulo, São Paulo, Brasil \\ emfeuzebio@hotmail.com
}

\begin{abstract}
RESUMO - As fronteiras têm sido estudadas a partir de diferentes abordagens, uma interpretação possível é sua análise a partir das formações socioespaciais dos países limítrofes considerando o espaço uma construção social sujeito a mudanças em cada contexto histórico. $\mathrm{O}$ objetivo da pesquisa foi compreender historicamente o processo de ocupação do subespaço atualmente compreendido pelas cidades gêmeas Tabatinga (Brasil) e Leticia (Colômbia) segundo suas respectivas formações socioespaciais; para isto foi elaborada uma periodização. O estudo permitiu verificar que a configuração socioespacial das cidades gêmeas foi condicionada pelo modelo de colonização, pelas modernizações impostas e, sobretudo, por questões geopolíticas clássicas e contemporâneas. Esses fatores atuaram de forma diferenciada em cada um dos quatro períodos delimitados.
\end{abstract}

Palavras-chave: Amazônia; fronteira; cidades gêmeas; Tabatinga e Leticia.

\section{THE GENESIS OF WEST FRONTIER OF AMAZON: THE TWIN CITIES TABATINGA (BRAZIL) AND LETICIA (COLOMBIA)}

\begin{abstract}
The borderlines have been studied from several approaches, one of these possible interpretations is the analysis of the sociospatial formations of the neighboring countries considering the space as a social construction bound to be changed in every historical context. The goal of the research was to historically understand the process of occupation of the subspace currently belonging to the twin cities of Tabatinga (Brazil) and Leticia (Colombia), according to their respective sociospatial formations; for this was drawn a timeline. The study allowed the verification of the suggestion that the sociospatial configuration of the twin cities was conditioned by the colonization model, the implemented modernizations, and, above all, by classic and contemporary geopolitical questions. These factors had different influences in each of the four periods of time.
\end{abstract}

Keywords: Amazon, boundary, twin cities, Tabatinga and Leticia.

\section{INTRODUÇÃO}

Tabatinga ultrapassou 65 mil habitantes em 2019 (IBGE, 2019¹) e Leticia, cidade vizinha colombiana alcançou 40 mil habitantes $\left(\mathrm{DANE}^{2}\right.$, 2018). Juntas, as duas cidades gêmeas fronteiriças situadas no interior da floresta amazônica ultrapassaram 100 mil habitantes. Um aporte populacional de $206 \%$ em quarenta anos, enquanto outras localidades num raio de até $500 \mathrm{Km}$ veem suas populações encolherem. O que explica a centralidade criada em volta desse subespaço? Quais processos históricos produziram essa fronteira? Sob quais condições essa cidades distantes dos centros políticos de seus respectivos países situadas no interior da Amazônia se desenvolveram e se organizam hoje?

Respostas imediatas poderiam ser postuladas se as cidades ao menos tivessem acesso rodoviário ou estivessem situadas próximas a algum centro produtivo dinâmico, mas ao contrário, 
Tabatinga localiza-se no extremo ocidental da Amazônia brasileira, à margem esquerda do rio Solimões, vizinha à cidade de Leticia na fronteira com a Colômbia, ambas estão a $1.105 \mathrm{~km}$ por via aérea à oeste de Manaus e $1.090 \mathrm{~km}$ ao sul de Bogotá. Conurbadas (NOGUEIRA, 2004), apenas divididas por uma fronteira seca, mantém uma relação do tipo "sinapse" (MACHADO, 2005), e juntas constituem um subespaço singular no que se refere ao aspecto natural, econômico, social, cultural e dinâmica territorial.

$\mathrm{O}$ estudo das fronteiras tem sido realizado a partir de diferentes abordagens e constitui um terreno amplo às Ciências Sociais com possibilidades de análise sob múltiplas metodologias. Uma interpretação possível e empregada nesse estudo foi sua análise a partir das formações socioespaciais dos países limítrofes, considerando o espaço uma construção social sujeito a mudanças em cada contexto histórico.

Sob esse prisma, o presente artigo procura fazer uma reconstituição histórica a fim de trazer a luz os fatores políticos, sociais, econômicos e culturais que conformaram esse subespaço fronteiriço. Para tanto foi elaborada uma periodização de cinco séculos a fim de interpretar o processo de gênese da fronteira ocidental da Amazônia brasileira, tendo em conta que o espaço geográfico é uma construção social, resultado entre outros fatores, das modernizações impostas ao longo da história.

Para Milton Santos, "modo de produção, formação social, espaço; essas três categorias são interdependentes" (2008a, p. 27), isto é, a noção de formação social deve conter o complexo das diferentes formas técnicas e organizacionais do processo produtivo, que correspondem às diversas relações de produção existentes não podendo ser concebida sem referência ao espaço. "As diferenças entre lugares são o resultado do arranjo espacial e dos modos de produção particulares" (Ibid., p. 28).

Considerações estas que nos remetem a refletir acerca do estudo das modernizações e da periodização como método necessário e fundamental ao entendimento dos lugares. Para Santos (2008b) "cada período é caracterizado pela existência de um conjunto coerente de elementos de ordem econômica, social, política e moral, que constitui verdadeiro sistema [...] modernização" (p. 31). E destaca ainda que a datação e a localização são fundamentais à atender o imperativo de se evitar incidência da "miopia temporal", isto é, o erro de interpretação por falta da devida consideração histórica (SANTOS, 2008b).

Sob tais circunstância, para efeito de método, elaboramos uma periodização envolvendo as duas formações socioespaciais no intuito de compreender os efeitos que estas impuseram sobre o subespaço originando especificidades locais. A dificuldade de execução advinda deve-se ao imperativo de se reunir e sincronizar temporalmente fatos relativos aos dois estados nacionais envolvidos (Brasil e Colômbia) e relacioná-los com as modernizações impostas no lugar. Contudo, acreditamos que o trabalho possibilita ao leitor uma leitura analítica e interpretativa do subespaço que o leva a compreensão tanto do processo genético da fronteira Brasil-Colômbia como das atuais e futuras possibilidades do subespaço Tabatinga-Leticia.

\section{Antes da fronteira (1494-1750): a expansão luso-castelhana de Tordesilhas à Madri}

O Tratado de Tordesilhas (1494) e o Tratado de Madri (1750) balizam a fase denominada PréFronteira, representando dois momentos de ruptura que afetaram os limites internacionais das nações ibéricas. Na virada do século XV para o XVI, Portugal e Espanha constituíam Estados Nacionais e potências marítimas iniciantes nas relações capitalistas de produção. As grandes navegações "descobriram" o "Novo Mundo", a América, viabilizadas inicialmente pelas empresas conquistadoras (privadas) e depois pelas colonizadoras (Coroa) que demandavam grandes investimentos. O desbravamento americano passou assim a fazer parte da política dos Estados, se imbricando às questões geopolíticas e geoeconômicas europeias (MACHADO, 1989). Sobre os fatores que levaram às expedições, Moraes (2000) explica que "as carências européias alimentaram a expansão, muito mais do que o espírito de cruzada, [...] motivos econômicos empurraram às expedições" (p. 73). 
A legitimação das terras descobertas pelos pioneiros: Espanha e Portugal foi realizada pela autoridade Católica e culminou com o Tratado de Tordesilhas (1494). Este dividiu o mundo em dois hemisférios delimitado por um meridiano distante 370 léguas a oeste de Cabo Verde, deixando à Espanha as terras ocidentais e à Portugal as orientais, baseado no princípio maré clausum aceito pelas coroas até final do século XVI (MACHADO, 1989).

Por ocasião da "descoberta do Brasil" em 1500 a "área amazônica pertencia à Coroa Espanhola, excetuando-se apenas uma pequena réstia de terras situada a leste da foz do Amazonas que pertencia a Portugal" (RIBEIRO, 2006, p. 41). A ocupação das terras brasileiras só se iniciou trinta anos após o "descobrimento" com a divisão da costa brasileira em capitanias (MORAES, 2000). Franceses, holandeses e ingleses investiram sobre a costa brasileira desde os primórdios da colônia e para manter a posse os portugueses firmaram o já implantado sistema de capitanias e distribuíram sesmarias (REZENDE, 2006).

Os franceses se fixaram ao longo da costa brasileira do Rio de Janeiro até o Rio Grande do Norte. Em São Luis (1613) ocorreram os primeiros combates para removê-los, a expulsão ocorreu em 1615 marcando o início da fixação portuguesa na Amazônia, o que para Rezende (2006), "representou verdadeiro marco na defesa do litoral no sentido leste-oeste, e assinalou o início da conquista e ocupação da hinterlândia amazônica" (p. 52).

\section{A descoberta do "rio das Amazonas" e a ocupação portuguesa iniciada por Belém}

O navegador castelhano Yañes Pinzón foi quem em 1500 anunciou ao Velho Mundo a existência do imenso mar de agua dulce do outro lado do Atlântico (HUERTAS, 2007). No entanto, foi Francisco de Orellana a serviço de Castela que partindo de Quito realizou a primeira navegação pelo Amazonas até o Atlântico em 1542. Relatos dizem que na viagem teriam sido atacados por nativos comandados por mulheres imponentes sem seio. A palavra grega a-mazón, sem seio, nomeou assim o rio das Amazonas (REZENDE, 2006).

A conquista da Amazônia teve seu início durante a União Ibérica ${ }^{3}$, quando ante a possível investida estrangeira sobre a região, a Coroa Espanhola bloqueou a navegação no rio Amazonas. Em 1616, a construção da Casa Forte do Presépio de Santa Maria de Belém (origem da cidade de Belém) permitiu aos portugueses "poner un pie en la cuenca amazónica" (ZARETE, 2012, p 23), pois que, a partir dali partiram as mais importantes expedições de conquista e exploração da coroa portuguesa (idem), o que significou o controle de acesso à vasta região amazônica e viabilizou a expulsão dos holandeses e ingleses do baixo Amazonas (REZENDE, 2006). Em 1623 os holandeses foram rechaçados indo se instalar onde hoje ficam as Guianas. Os ingleses também foram desmobilizados pelas expedições portuguesas comandadas por Pedro Teixeira. A Capitania das Índias Ocidentais conquistou Pernambuco em 1630 e de lá se estendeu até o Maranhão (MACHADO, 1989). Para Reis (1948), tais esforços demonstram as intenções da Coroa Ibérica em conquistar a região e estender-se mais ao norte, preservando a entrada do rio Amazonas sob seu controle (apud REZENDE, 2006). A União Ibérica foi extinta em 1640 e o Brasil voltou ao domínio de Portugal. A Amazônia, porém, segundo Tordesilhas continuava sob o poder da Espanha, situação que os portugueses não aceitavam. A região da grande selva ficou dessa forma, durante 110 anos em situação nebulosa, até a assinatura do Tratado de Madri, em 1750 (RIBEIRO, 2006).

\section{As ordens religiosas e os fortins portugueses: estratégia de ocupação}

No início do século XVII, a coroa portuguesa passou a distribuir as ordens religiosas ao longo do vasto território amazônico como estratégia de ocupação e manutenção territorial (MACHADO, 1989). Os Franciscanos foram os primeiros a chegar ao Amazonas em 1616, seguidos pelos Carmelitas em 1624, depois dos Mercedários vindos de Quito com Pedro Teixeira em 1639, e finalmente os Jesuítas, trazidos pelo Padre Antônio Vieira em 1652-53. O mapa abaixo demonstra a distribuição das ordens religiosas no Amazonas. 
Figura 1. Distribuição das Ordens Religiosas no Amazonas

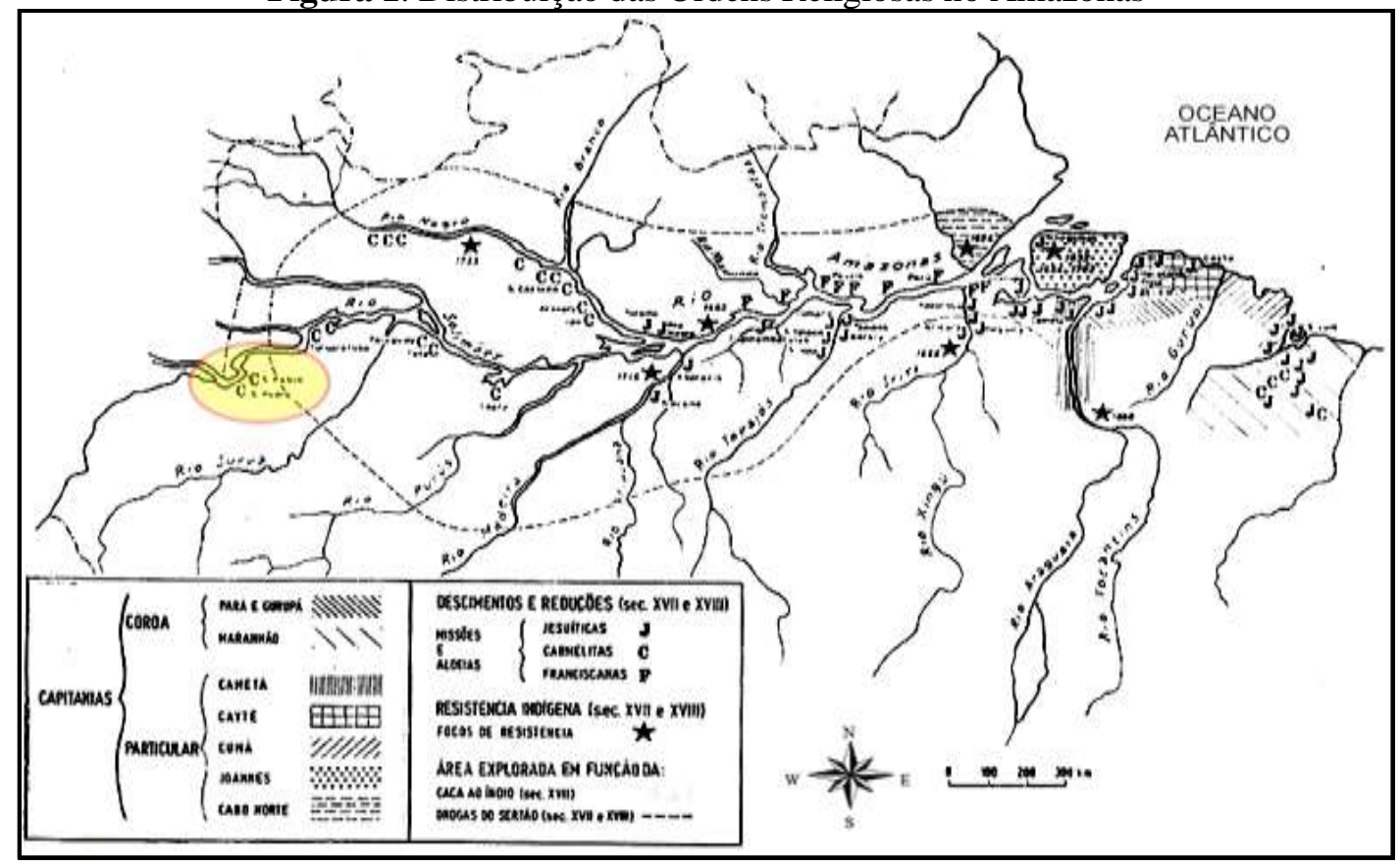

Fonte: MACHADO (1989), adaptado pelo Autor

A organização das missões permitia a subsistência e a produção de excedentes que eram comercializados com isenção de dízimos ou taxas aduaneiras em Lisboa. Segundo Machado (1989), em 1751, a população total das missões foi estimada em 12 mil habitantes. Uma população pequena relativamente à área considerada, no entanto, parece ter sido suficiente para garantir durante todo o período a posse portuguesa.

Após 1750, a instalação de fortins militares em locais estratégicos da colônia foi a consecutiva estratégia territorial portuguesa. Para Machado (1989), os fortins tinham mais significado simbólico do que militar dada a precariedade das construções e a limitação de suas tropas. No entanto, "[...] a construção de fortes em localizações estratégicas bem ilustra a visão geopolítica que presidia a conquista lusitana da Amazônia" (MORAES, 2000, p. 398). Por outro lado, "a forma menos custosa para garantir o domínio [...] amazônico [...] da época, era, sem dúvida, a missão religiosa" (MACHADO, 1989, p. 40). Moraes (2000) resume a estratégia dizendo que "foi nessa área que a instituição religiosa melhor desempenhou o papel congênere na função de ocupação e afirmação da soberania" (p. 400).

\section{A expedição de Pedro Teixeira baliza a fronteira entre as duas colônias}

A expedição de Pedro Teixeira pelo rio Amazonas/Solimões desde Belém até Quito no Equador (1637-1639) ainda em vigência da União Ibérica significou a tomada de posse da região para Portugal em nome do Rei da Espanha e veio a balizar a fronteira entre as duas nações (GADELHA, 2002). Moraes (2000) aponta que essa bandeira foi a "mais dilatada das expedições exploradoras [...] e que constituiu tentativa de desalojamentos dos núcleos estrangeiros e instalação de bases portuguesas no vale do grande rio" (p. 397). Pedro Teixeira propiciou a infiltração dos portugueses pelo vale amazônico até aproximadamente 1740 (um século). Período em que ocorreram muitas Ordens Régias, expedições e conflitos entre portugueses e espanhóis pelo controle ocidental do vale do rio Solimões.

Outra estratégia de controle territorial empregada durante a União Ibérica que foi mantida por Portugal após 1640 foram os territórios diretamente subordinados à Metrópole. Um exemplo foi o Estado do Maranhão criado em 1621, politicamente independente do Brasil e subordinados ao governo geral de São Luis (REZENDE, 2006). Portugal ainda empregou como estratégia de 
ocupação do interior da Amazônia o estabelecimento da economia regional conhecida como "drogas do sertão" para a comercialização na Europa.

\section{A ocupação colombiana começa pelo Caribe}

A ocupação da colônia espanhola que veio a conformar a atual Colômbia, se iniciou pelo norte da América em circunstâncias diferentes da portuguesa. A colonização espanhola buscava metais preciosos e a ocupação de novos territórios. A economia européia deficitária requeria urgente uma fonte de riqueza para o comércio a fim de conservar os preços das manufaturas. Assim a economia colonial entre os séculos XVI, XVII e XVIII se baseou na busca por ouro e prata e assim se vinculou à economia-mundo (VARGAS, 1999).

A ocupação se deu pelo Caribe, sendo as primeiras cidades fundadas Santa Marta, Cartagena e Riohacha. Após a descoberta do rio Magdalena, artéria fluvial no sentido norte-sul em meio à cordilheira, se iniciou a conquista do interior. No alto do planalto em 1537 foi fundada a cidade de Santa Fé de Bogotá, e nos anos seguintes: Pasto, Cali e Cartago. Outro eixo de povoamento aconteceu pela área onde hoje fica o território venezuelano, atravessando os "Llanos" até juntar-se na vertente oriental da cordilheira. Praticamente todas as cidades fundadas tiveram distritos mineiros e usavam mão de obra indígena, até que essa se esgotou e foi substituída pelos escravos negros (VARGAS, 1999).

O esquema jurídico-formal que estruturou a economia e o poder colonial foi a encomenda ${ }^{4}$. Geograficamente o gado se alastrou pelos vales interandinos e nas áreas agropastoris se formaram grandes latifúndios originando uma colcha de espaços descontínuos que formaram uma proto-rede urbana subordinada ao império espanhol. O restante do território compunha-se de extensas áreas baldias, isoladas e improdutivas e funcionava como um apêndice econômico da Coroa, primeiramente extrativista e depois agrícola. O crescimento demográfico e econômico e o novo cenário geopolítico mundial deram as condições para a Gran Colombia tornar-se independente em 1819, após quase dez anos da guerra liderada por Simón Bolívar (VARGAS, 1999). A ocupação do vale do Amazonas, por sua vez, até a primeira metade do século XVII não ultrapassou a região de Quito, do rio Napo e Javari até Iquitos. Os recursos necessários e o obstáculo da cordilheira fizeram os espanhóis não investir sobre o vale amazônico, preferindo buscar o El Dorado no Peru, mais ao sul, então vice-reino de Nova Granada (GADELHA, 2002, apud REZENDE, 2006).

\section{A ação jesuítica no território colombiano e a disputa pelo vale do rio Solimões}

A partir do século XVII os espanhóis passaram aos religiosos a missão de defesa dos territórios coloniais mais extremos. Desde então, reduções jesuíticas iniciaram a conquista a partir de Quito (Equador) e Pasto (Colômbia), penetrando até Borja ${ }^{5}$ (Peru) às margens do rio Marañon onde fundaram a província de Maynas, com 80.000 indígenas em 1660 (MACHADO, 1989). Amparado no Tratado de Tordesilhas, Samuel Fritz, da Companhia de Jesus, veio da Europa contratado pela Espanha para catequizar a região. Entre 1686 e 1704, fundou mais de trinta reduções na região dos Omáguas. Em 1689, Fritz iniciou a descida pelo rio Amazonas adentrando pelo terreno ocupado pelos portugueses ao longo dos rios Marañon e Solimões. Fundou ao longo desse último, as missões de Taracueteua (Nossa Senhora de Guadalupe), São Paulo dos Cambebas (São Paulo de Olivença), Amaturá (Castro de Avelães), Santa Teresa do Tape (Tefé) e Santana do Coari (Coari), todas em rotas já identificadas portuguesas desde 1660 (LOREIRO, 1978 apud REZENDE, 2006, p.135). O mapa seguinte sintetiza as principais ações empreendidas.

Em represália, Lisboa ordenou a expulsão dos espanhóis do rio Solimões, e desde então, a ocupação e manutenção do vale amazônico recebeu prioridade. Os portugueses fundaram missões no rio Japurá e Javari que ajudaram a delimitar a futura fronteira. Por volta de 1750 na confluência dos rios Marañon e Javari, foi construída a missão de São Francisco do Javari, atual cidade de Benjamin Constant, hoje limite entre Brasil e Peru. 
Figura 2. Expedições, reduções espanholas e fortificações na Amazônia.

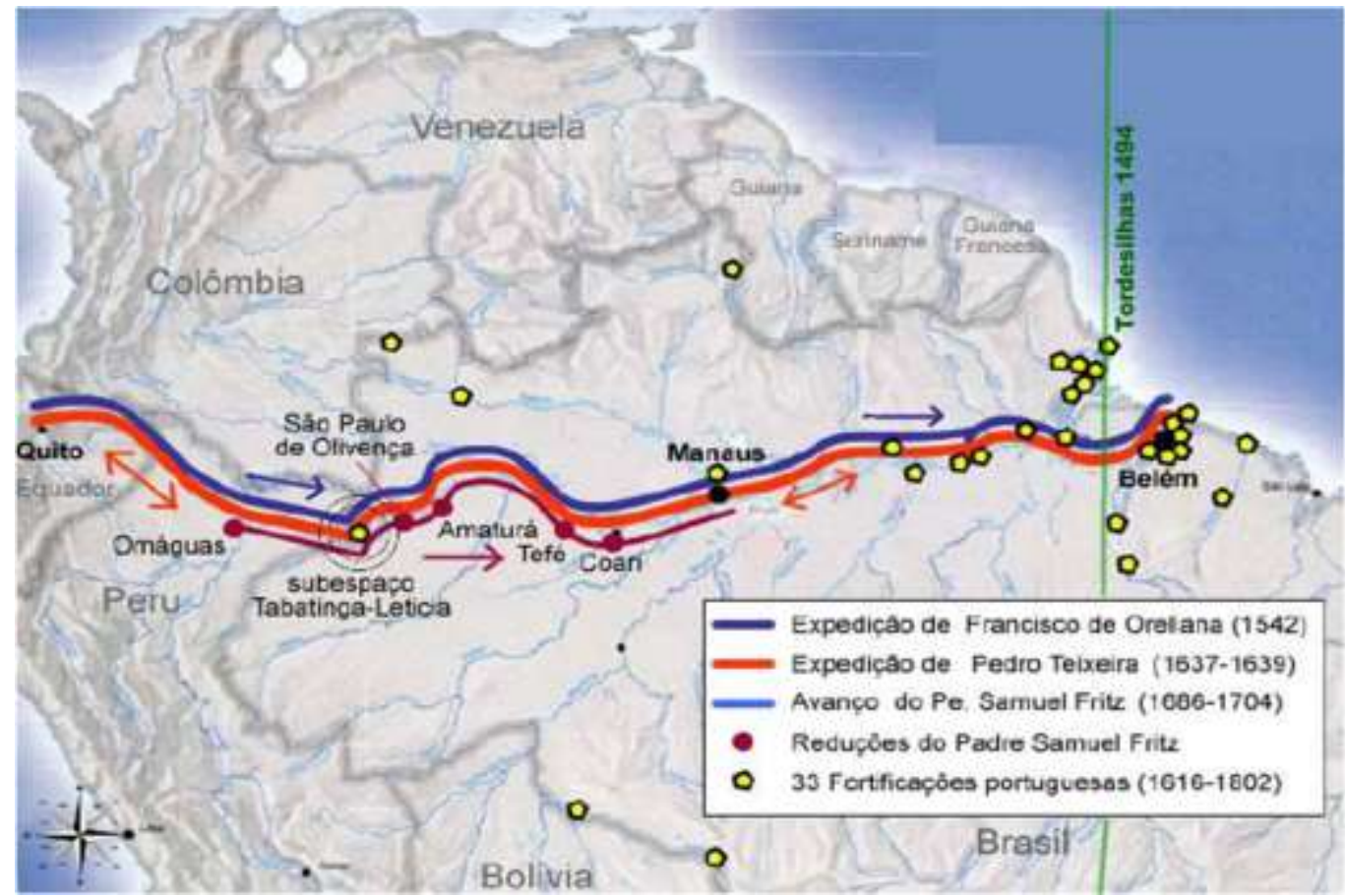

Elaboração: Adaptado pelo Autor de (RIBEIRO, 2006).

Os fatos caracterizam a disputa pela ocupação e controle da região vivida entre os espanhóis que desciam o vale do Amazonas e os portugueses que subiam no sentido contrário, "era inevitable que el acceso y el control del gran río se convirtieron en principal propósito de unos y otros" (ZARETE, 2012, p. 24), com referência as suas expectativas territoriais, interesses econômicos e organização política e militar.

A esse respeito, a história revela também, nesse e em outros fatos, como portugueses e espanhóis construíam fortes e missões. Todavia, os portugueses, de modo geral, para demarcar e resguardar as fronteiras, erigiam fortins militares enquanto os espanhóis predominantemente usaram os "pueblos de misión" para este fim (ZARETE, 2012).

As ações portuguesas de ocupação do interior da região amazônica foram apoiadas pelos acordos estabelecidos com a Inglaterra em 1642, 1654, 1661 e o Tratado de Methuen (1703). Tais acordos deram fôlego à política colonial portuguesa e revigoraram as ações de defesa na colônia tendo vários efeitos para o vale do Amazonas. Entre 1640 e 1740 várias expedições foram realizadas com vistas à ocupação e/ou expulsão dos franceses e espanhóis; capturar escravos; levantar fortins e encontrar ouro (MACHADO, 1989). A esse respeito Moraes (2000) afirma que "até o final do século XVII as bases da formação territorial do Brasil estavam dadas, isto é, a soberania lusitana estava reafirmada" (p. 401).

\section{CONSTITUIÇÃO DA FRONTEIRA (1750-1938): DA DISPUTA PELA BORRACHA NASCE A FRONTEIRA}

\section{O Tratado de Madri dá início à conformação das fronteiras na Amazônia}

Desde quando os portugueses ocuparam a foz do rio Amazonas e fundaram Belém (1616) até o Tratado de Madri (1750), a Amazônia formalmente pertencia à Espanha, por força do Tratado de Tordesilhas, entretanto, de fato, era ocupada por Portugal. Nesse ínterim se passaram 134 anos de 
indefinições geopolíticas (RIBEIRO, 2006). A partir do reinado de Dom João V (1706-1750), Portugal deu prioridade à definição das fronteiras coloniais resultando no Tratado de Madri, legalizando-se estas segundo o princípio jurídico da posse pelo uso (uti possidetis), o qual beneficiou Portugal que durante a União Ibérica (1580-1640) e depois quando reforçado politicamente pelos acordos com a Inglaterra (1642-1703), explorou as terras a oeste para muito além do Meridiano de Tordesilhas.

Portugal empreitou uma profunda reorganização política, econômica, social, jurídica e religiosa sobre a Amazônia e o Centro-Oeste do Brasil, se propondo a ocupar e povoar para garantir a defesa e posse. Com base no Tratado de Madri o Brasil teve sua área territorial mais que triplicada (REZENDE, 2006) e concedeu ao Brasil, salvo pequenas modificações, como o acréscimo do Acre em 1903 e a definição da linha Apaporis-Tabatinga com a Colômbia em 1907, aproximadamente, a sua atual configuração geográfica.

\section{A política territorial pombalina: a substituição das missões religiosas pelos fortins}

Concomitantemente ao Tratado de Madri (1750), inicio-se o período "Pombalino" marcado pelo confronto entre o modelo de controle territorial interno religioso e o externo voltados às relações comerciais Metrópole/Colônia (MACHADO, 1989). O Marquês do Pombal ${ }^{6}$ influenciou a expulsão das ordens religiosas de Portugal e das colônias em 1759 e passou o controle territorial aos militares. Politicamente, Pombal desejava conduzir o governo colonial sob o novo contexto do mercantilismo crescente, no entanto, o modelo não logrou associar controle territorial e base econômica como as missões haviam conciliado. O legado missionário, opostamente, até meados do século XVIII havia estendido aldeias do Paraguai até os Maynas (Peru), criando uma verdadeira linha de fronteira disposta no sentido norte-sul que subsidiou o Tratado de Madri, e foi um dos principais responsáveis pelo traçado da fronteira oeste brasileira (MACHADO, 1989).

Foi nesse período que se fundaram os assentamentos mais extremos das respectivas coroas sobre o rio Amazonas, Nuestra Señora de Loreto de Ticunas em 1760, por parte dos espanhóis, e poucos ano depois cerca de $60 \mathrm{~km}$ mais abaixo, o Forte de São Francisco Xavier de Tabatinga em 1770, pelos portugueses. (ZARETE, 2012, p. 33). Tal forte militar visava assegurar a posse do território às vésperas do Tratado de Santo Ildefonso (1777), acabou originando um povoado que foi elevado a categoria de Freguesia em 1850, integrado ao município de São Paulo de Olivença em 1891, e por com a criação do município de Benjamin Constant em 1898, passou a configurar como seu distrito (REZENDE, 2006), e constituiu a pedra fundamental da atual Tabatinga.

\section{A conformação territorial e a constituição da nação colombiana}

A invasão napoleônica à península ibérica em 1808 e a desestabilização do poder das Coroas Ibéricas sobre suas colônias possibilitou a independência da República de la Gran Colombia em 1819 (VARGAS, 1999), provocou a transferência da Coroa Portuguesa ao Brasil em 1807 e viabilizou a independência do Brasil em 1822 (RIBEIRO, 2006).

Na Colômbia, desde 1850 começou a se intensificar o comércio exterior de produtos primários associados à introdução da navegação a vapor, de obras, técnicas, modificações econômicas, administrativas e fiscais. Em 1858 se formou a Confederação Granadina, em 1863 os Estados Unidos da Colômbia, em 1886 denominou-se República da Colômbia e fez nascer em 1891 a primeira Constituição Republicana Colombiana.

A partir de 1870 , o café se tornou o principal produto colombiano, atingindo $50 \%$ das exportações, associado a este criou-se uma economia que provocou um impulso fluvial, ferroviário e rodoviário gigantesco que criou as condições para a articulação do território colombiano incluindo a inserção do telégrafo a partir de 1865 (VARGAS, 1999).

Em 1886 esgotou-se o modelo liberal colombiano e mudanças na ordem política, econômica e social culminaram na Constituição de 1886 que estabilizou o país até a depressão de 1930. Nesse período a Colômbia se consolidou mundialmente como exportador de produtos primários puxada pela 
expansão do café. Isso possibilitou a mudança da base técnica, a formação do mercado interno e a expansão da produção de modo geral (VARGAS, 1999). Essas mudanças, no entanto, não alcançaram territorialmente o oriente da selva amazônica colombiana fronteiriça ao Brasil e ao Peru.

\section{As caucherías da selva oriental colombiana despertam a fronteira}

A região da selva oriental colombiana, fronteiriça ao Brasil, permaneceu abandonada desde 1767, quando os Jesuítas foram expulsos por Carlos III. Somente em 1870 a região dos rios Caquetá, Putumayo e Amazonas teve sua situação alterada devido à penetração dos primeiros quineiros ${ }^{7} \mathrm{e}$ caucheiros $^{8}$ brasileiros, colombianos e peruanos. Em 1905 os peruanos passaram a competir pela borracha em território colombiano, levando ao enfretamento das tropas dos dois países em La Pedrera em 1911. Mesmo assim, a Casa Aranha ${ }^{9}$ permaneceu comprando dos caucheros colombianos até apoderar-se de toda a região, desencadeando mais tarde outro armistício com o Peru em 1932 (DOMÍNGUEZ, 1985).

Somente na segunda metade do século XIX começou a ação colombiana sobre a área do baixo Putumayo. Provocada por comerciantes, extratores de plantas medicinais e seringueiros que começaram a reclamar para si e para a Colômbia as áreas onde se assentavam. Segundo Domingues (1985) o país deve a estes grupos a manutenção de tal território:

El país debe a los caucheros el haber podido defender sus fronteras en esa región, ya que oficialmente nunca se preocupó por hacerlo hasta muy entrado el siglo XX. [...] Esas fuerzas encontradas de misioneros, comerciantes, caucheros, soldados y funcionarios (ante la presencia inconsulta del indígena), se firma un Tratado de Límites entre Colombia y Brasil en 1928, precediendo a colocar los hilos, trabajo que se terminó de realizar en 1936 hasta el rio Apaporis y en 1937 hasta Leticia (ANDRADE, 1965 apud DOMÍNGUEZ, 1985, p. 145).

Durante essa fase, na Colômbia ocorreu um processo de colonização e abertura das fronteiras internas. Tal processo se deu a partir de 1850 através da política dos baldios ${ }^{10}$ a qual favoreceu o povoamento progressivo do oriente colombiano: mais a Orinoquia e pouco a Amazônia (VARGAS, 1999). O período de colonização se deu entre 1850 e 1930 e esteve associada à exploração da borracha, da quina e de fibras naturais.

\section{A fundação de Leticia em território peruano}

Quase cem anos depois do Forte de São Francisco Xavier de Tabatinga ser erigido em função do tratado assinado entre Brasil e Peru de Livre Navegação sobre o rio Amazonas (1851). Em 25 de abril em 1867, o Capitão peruano Benigno Gustamante fundou Leticia, como um porto fluvial peruano, inicialmente chamada de San Antonio com vistas a adiantar a construção do fortim que se chamaria "Mariscal Ramón Castilla [...] [que] no se culminó, pero si continuó con vida el poblado de Leticia" (ACUÑA, 2012, p. 98), cuja população até o final do século XIX não ultrapassou 50 famílias.

No início do século XX o "boom" do extrativismo capitalista das gomas elásticas transformou a vida social e urbana da Amazônia, incluindo Leticia que passou à posto aduaneiro (1900) inserindo-se na dinâmica econômica mundial da época e, em função disso, recebeu significativo aporte de infraestrutura, dentre os quais se inclui a escola de práticos (1907) e a comunicação sem fio com Iquitos (1916). No entanto, a partir de 1921, por conta da quebra da economia da borracha, o casario de Leticia foi convertido em Comisaría Fluvial, depois a Puesto Militar e, por fim, em 1930, o Tratado de Lozano-Salomón transferiu Leticia ao domínio da Colômbia. (ACUÑA, 2012; COLOMBIA, 1979).

\section{A economia da borracha e a produção do espaço amazonense}

No período seguinte à Independência (1850 e 1920) um evento exógeno trouxe à região norte um impulso econômico e demográfico com repercussão na organização urbana. "A descoberta do processo de vulcanização da borracha pelo norte americano Goodyear [tornou] o interior da floresta um dos principais alvos do capitalismo internacional" (HUERTAS, 2007, p. 32) conduzindo ao que ficou conhecido como o boom da borracha ${ }^{11}$. 
A economia da borracha inseriu a Amazônia no mercado internacional e capitais nacionais e estrangeiros mobilizaram-se para a região trazendo a navegação a vapor ${ }^{12}$ e fortalecendo $o$ mecanismo de aviamento ${ }^{13}$. Mais de 300 mil imigrantes, sobretudo, vindos do nordeste brasileiro, chegaram a fim de suprir a escassez de mão-de-obra, movimento nomeado por Furtado (1971) como "transumância amazônica". A peonagem e a escravidão por dívida caracterizaram as relações de trabalho. Novos núcleos de povoamento surgiram, núcleos anteriores foram revigorados e Manaus foi elevada à Capital em 1852.

Nessa fase Manaus e Belém foram os receptáculos da modernidade advinda da Revolução Industrial o que ficou conhecido como a Belle Époque. Grandes firmas estrangeiras se instalaram em Manaus e prédios suntuosos foram construídos. "Diante dos olhos do mundo, Manaus [...], [ficou conhecida] como a "nova paris' grande cidade moderna e atraente da Amazônia" (HUERTAS, 2007, p. 39). A economia gerada financiou a modernização do transporte fluvial e a interiorização dos fluxos até pontos remotos da selva, sobretudo a sudoeste, área dos rios Madeira, Purus e Juruá, ocupados pelos seringueiros.

Na região do Alto Solimões a goma não atingiu grande volume. "O Alto Solimões figurava entre as áreas produtivas menores, sendo comum que as casas aviadoras de Manaus e Belém a registrassem sob a rubrica de Iquitos ${ }^{14}$ juntamente com a goma proveniente do rio Javari e do Peru" (OLIVEIRA, 1998, p. 77). Nesse período, "Leticia abrigava um entreposto de comercialização, onde as casas aviadoras de Iquitos no Peru compravam esse produto extrativo" (NOGUEIRA, 2008, p. 170). A goma extraída na região mais beneficiou a economia peruana do que a brasileira, dado que o sistema de aviamento da Casa Aranha até aí alcançava. A crise da borracha iniciada em 1919 desorganizou a economia regional de tal forma que entre 1920-1960, a Amazônia viveu um longo período de estagnação econômica e involução urbana (CORRÊA, 1989). Tais efeitos afetaram igualmente a economia da goma peruana e colombiana que se somava à brasileira no Alto Solimões.

\section{Os tratados de limites no início do século XX e o Conflito de Leticia}

A emergência pela definição dos limites internacionais entre Colômbia-Peru e Colômbia-Brasil ocorridos no início do século XX, se deu, sobretudo, devido à economia da borracha que exigia a determinação quanto ao pertencimento daquela área da floresta amazônica. Os limites entre os três países, em tese haviam sido alinhavados desde o advento das Repúblicas (Colômbia, 1819; Brasil, 1822 e Peru, 1824). Contudo, o extremo sul da selva colombiana, nunca fora de fato ocupada. Somente agora, impulsionado pela goma explorada pelos colonos pioneiros colombianos é que a Colômbia manifestava seu interesse na região, quando já estava tomada por caucheros peruanos há quase três décadas.

O limite internacional entre Brasil e Peru havia sido estabelecido desde 1851 quando foi firmado o Tratado de Comércio, Navegação e Limites (Tratado de Lima). No entanto, a divisa entre Colômbia, Peru e Equador ainda não estava resolvida. Equador e Colômbia definiram suas fronteiras somente em 1916 através do Tratado Suárez-Muñoz Vernaza. A divisa internacional Brasil-Colômbia foi firmada pelo Tratado de Bogotá ${ }^{15}$ firmado em 1907 e ratificado em 1928 (Rio de Janeiro) e em 1930 (Bogotá), depois de confirmados os limites entre Colômbia e Peru. Em ambos os acordos: Brasil-Colômbia e Brasil-Peru a linha geodésica Apaporis-Tabatinga era quem delimitava o limite internacional desses países com o Brasil, isto é, as duas nações reivindicavam a posse territorial sobre mesma linha.

O Tratado de Limites e Navegação Fluvial Lozano-Salomón firmado entre Colômbia e Peru em 1922, em Lima, significou o início da determinação da fronteira entre esses países. Pelo acordo, Colômbia adquiria o Trapecio Amazónico ${ }^{16}$ obtendo uma saída ao rio Amazonas, o Peru ficava com toda a margem direita do rio Putumayo e ambos obtinham o direito à navegação nos rios da região (COLOMBIA, 1979). A ratificação do Tratado só aconteceu em 1925, com o apoio de Washington, e finalmente foi ratificado pelos três países em março de 1928. Os trabalhos de 
demarcação realizados pela Comissão Mista de Demarcação de Limites se iniciaram em 1930 e encerraram em 1937 (COLOMBIA, 1982). O mapa contido na figura abaixo esquematiza espacialmente os limites citados.

Figura 3. Tratados de limites internacionais entre Brasil-Colômbia e Colômbia-Peru

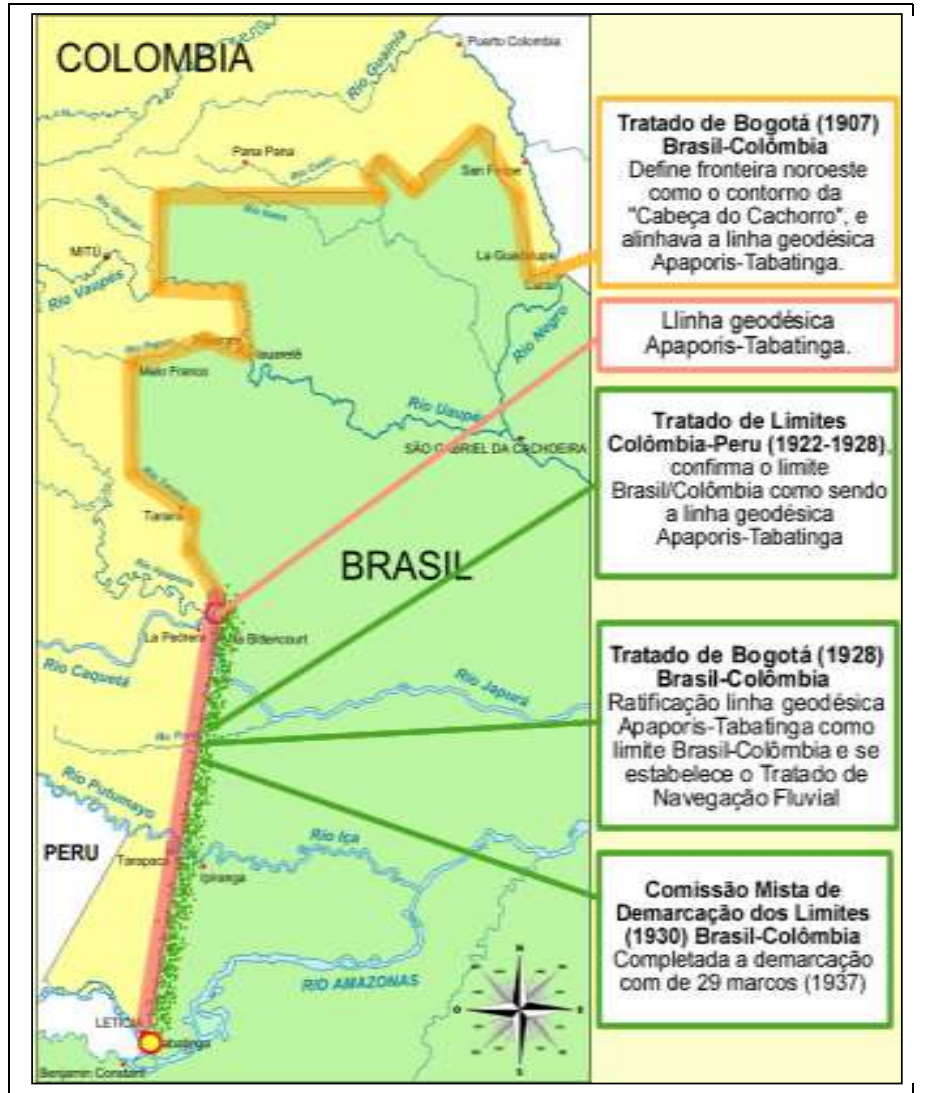

Fonte: adaptado pelo Autor, com base em (COLOMBIA, 1979, 1982, 1994).

Entre 1919 e 1930 vigorou no Peru uma fase ditatorial, o General Sánchez Cerro explorou o descontentamento dos peruanos caucheros que exploravam a região desde 1890 em ceder o Trapézio Amazônico à Colômbia, e um grupo de loretanos apoiados pelo governo de Loreto invadiu Leticia em setembro de 1932 (Conflito de Leticia) (ZARETE, 2012). Para expulsar os peruanos, o General colombiano Alfredo Vásquez Cobo angariou junto à França, Inglaterra e Espanha uma flotilha que subindo pelo Amazonas/Solimões retomou Leticia em março de 1934 (COLÔMBIA, 1994). Ao final do conflito, a Colômbia criou a Comisaría Especial del Amazonas em Leticia, a fim de conceder maior poder político ao Trapézio Amazônico. Percebe-se que desde o final do conflito bélico, o governo central colombiano passou a ter Leticia como localidade de distinto valor geopolítico. Fato que nos remete a Raffestin (1993) quando afirmou que "o espaço não é significativo por si mesmo: ele só significa alguma coisa quando ligado a uma intenção" (p. 189).

\section{CONSOLIDAÇÃO DA FRONTEIRA (1938-1981): VERTICALIDADES INSTITUCIONAIS CONSOLIDAM A FRONTEIRA}

A consolidação da fronteira Brasil-Colômbia iniciou-se no final da década de 1930 quando 
políticas nacionais começaram a ser implantadas no contexto da nova conjuntura geopolítica e econômica mundial. Os limites haviam sido definidos, faltava agora tornar aquele subespaço fronteiriço "vivo" e conectá-lo aos respectivos espaços nacionais. Nesse mesmo encaminhamento, em 1938 a Colômbia estabeleceu o Convênio de Cooperação Aduaneira entre Colômbia e Peru (CCACP), com vistas a fomentar o comércio, a navegação e promover o desenvolvimento regional da região fronteiriça. Este, posteriormente foi ampliado e permanece em vigor até hoje (COLOMBIA, Ley nº 160, 1938).

\section{O Estado Novo, os Territórios Federais e a Amazônia}

Até a década de 1930, a situação política do Brasil foi marcada por crises políticas recorrentes, no final do período, o Crash de 1929 desencadeou uma crise econômica que deflagrou mudanças políticas que permitiram a ascensão de Getúlio Vargas ao poder em 1930, em seguida da promulgação da Constituição de 1934 e do Estado Novo (1937-1945), cuja instalação fez o governo brasileiro assumir um caráter autoritário e centralizador, porém com importantes repercussões econômicas, sociais e territoriais. $\mathrm{O}$ aparelho estatal foi modernizado por meio da criação de órgãos públicos e estatais voltados a promover o desenvolvimento nacional. Para Costa (1997) "a Constituição de 1934 foi de fato liberal e modernizante do país" (p. 45).

O Correio Aéreo Nacional (1931), por exemplo, viabilizou a presença militar no interior do país e abriu novas rotas aéreas ligando as populações do interior ao centro do país (CARVALHO, 1963 apud HUERTAS, 2007, p. 48). Segundo Costa (1997) as iniciativas do período 1930-40, estavam em consonância com as tendências dominantes da relação Estado/Economia dos países capitalistas centrais da época que orbitavam sobre os princípios da economia keynesiana. A exemplo dos Estados Unidos que vivia a política do New Deal.

O Estado Novo iniciou uma nova divisão política, administrativa e territorial na Amazônia. A esse respeito, Lysias Rodrigues ${ }^{17}$ (1947) considerava que havia um entrave histórico à evolução político-social do Brasil de cunho geopolítico. Cobrava ele uma nova divisão territorial tendo em vista que $93 \%$ da população estava localizada ao leste do território, enquanto apenas $6 \%$ ficava a oeste, sendo que esta ocupava $64 \%$ da área total do país, ou seja, era praticamente despovoada. Também Mário Travassos (1947), dizia que era necessário interconectar o arquipélago brasileiro, ligando a Amazônia ao resto do país. "Os grandes vales são verdadeiros eixos de compartimentação econômicos" (p. 69), e que goza o Brasil "[...] de privilegiada condição fisiográfica em favor da unidade territorial no que se refere ao papel vinculador das vias fluviais especialmente o vale amazônico" (p. 122). Considerações pertinentes, haja vista que até o final da Segunda Guerra a "Ilha Amazônica" somente tinha comunicação ao restante do país pelo meio fluvial-marítimo.

A criação de cinco Territórios Federais ${ }^{18}$ nas áreas fronteiriças (1943), controlados pelo governo federal com vistas a dotá-los de fixos necessários à educação, saúde, energia, água potável, vias de acesso e repartições públicas foi a forma política encontrada para sobrepor os regionalismos locais (RODRIGUES, 1947). Entre os eventos desta fase com repercussão na Amazônia, podemos citar: demarcação da fronteira Brasil-Colômbia (1937); transformação da Superintendência de Defesa da Borracha (1912) no Banco de Crédito da Borracha (1942); o segundo ciclo da borracha "Soldados da Borracha"19 (1943-1945); e a concessão de foro de cidade aos municípios de São Paulo de Olivença e Benjamin Constant (1938), constituidores do Alto Solimões à época (MENEZES, 2009).

\section{A II Guerra Mundial abala a geopolítica mundial e desperta a Amazônia}

A II Guerra Mundial abalou a geopolítica mundial e fez o Brasil refletir sobre sua relação com a Amazônia. A queda de Getúlio (fim do Estado Novo) e a Constituição de 1946 pôs a questão amazônica na pauta política sob o viés da integração nacional. Donde veio a renovação da SNAPP ${ }^{20}$, a implantação de sistemas de energia em Manaus e Belém e o início da construção das estradas de integração nacional (RIBEIRO, 2006). 
A partir de 1946, dispositivos constitucionais foram criados a fim de atender os problemas regionais, destaca-se entre a instituição da Amazônia Legal ${ }^{21}$ apoiada pelo primeiro Plano Qüinqüenal $^{22}$ (1955-1959). Getúlio, em seu segundo governo, deu continuidade em ritmo acelerado às políticas voltadas à infraestrutura, energia e transportes, constituindo as condições que viabilizaram o crescimento industrial e econômico verificado no período seguinte do governo Juscelino Kubitschek (JK) e o Plano de Metas.

Dentre as ações contidas no Plano de Metas de JK (1957-1960), as que mais afetaram a fluidez territorial foram a construção de $12 \mathrm{mil} \mathrm{km}$ de rodovias nacionais e a pavimentação de 7.215 $\mathrm{km}$, dando uma nova configuração às relações inter-regionais do país (COSTA, 1997). Também a construção de Brasília marcou o início das grandes obras de valor geopolítico que vieram a interligar o "vasto arquipélago" brasileiro (COSTA, 1997, p. 65). Ela serviu de nó de articulação territorial, concomitantemente à construção das rodovias: Belém-Brasília; Acre-Brasília; Fortaleza-Brasília; Belo Horizonte-Brasília; e, Goiânia-Brasília. Acerca disso, Travassos (1947), e Santos e Silveira (2001) asseveram que Brasília [...] induziu a construção de uma rede de rodovias sobre o conjunto do território, contribuindo para a expansão e articulação do consumo interno" (p. 46). E quanto à Amazônia, Couto e Silva (1981) propunha "inundar de civilização a hileia amazônica" (p. 47), ideias que basearam as ações realizadas pelos governos civis e militares das décadas seguintes.

\section{O período militar, a Integração Nacional e a Amazônia}

A integração da Amazônia ao país foi tática dos militares a partir de 1964 como resposta geopolítica à cobiça internacional e "Integrar para não entregar" foi o lema (RIBEIRO, 2006). Concepção que o governo central entendeu como condição ao desenvolvimento econômico e social do país, em especial à Amazônia e ao Nordeste. Como instrumento o governo criou "superórgãos" e Planos de Ação. Para Costa (1997), esta fase, representou um aprofundamento do processo de modernização centralizada e do Estado autoritário.

Uma nova política de desenvolvimento para a Amazônia foi estabelecida a partir de 1965. Em 1966, o Presidente Castelo Branco lançou a "Operação Amazônia". Em seguida, foi criada a $\mathrm{SUDAM}^{23}$, o BASA ${ }^{24}$, o MINTER ${ }^{25}$ e incentivos fiscais foram concedidos. O Plano Decenal de Desenvolvimento Econômico e Social (1967-1976) explicitou a questão regional e a integração nacional como objetivo maior do Estado.

O governo subsequente (1968-1970) acrescentou outras diretrizes de integração nacional para a Amazônica Legal. O I PND ${ }^{26}$ (1972-1974) significou o principal plano global de desenvolvimento, conjugando integração nacional e expansão da fronteira econômica no sentido Centro-Sul, Centro-Oeste, Amazônia e Nordeste (ANDRADE, 2001). O PIN²7, instituído em 1970, durante o "milagre econômico brasileiro", representou o alargamento das fronteiras econômicas internas do país (COSTA, 1997). E visava "rasgar a imensa floresta amazônica de leste a oeste e de norte a sul, encravando em seu âmago uma cruz rodoviária que fosse capaz de descortinar as riquezas escondidas em seu subsolo e proporcionar a colonização da selva, integrando-a à vida nacional" (HUERTAS, 2007, p. 99).

O II PND (1975-1979) buscou estimular as exportações e a ocupação das "áreas vazias" do território, empregando para isso, capitais privados nacionais, estrangeiros e investimentos governamentais (COSTA, 1997). Assim o Estado, através de grandes projetos e incentivos fiscais promoveu uma modernização e a transferência de capitais para a periferia, marcando a fase denomina por Berta Becker (1994) de "modernização conservadora" (p. 148). Na análise de Cataia (2001), "os militares sedimentaram uma camada técnica sobre o território brasileiro que possibilitou hoje os presentes sistemas técnico" (p. 131). E Becker (2009), situa a ocupação da Amazônia (1970-1985) como um avanço da fronteira como recurso econômico. Segue abaixo um quadro síntese das ações estatais do período (1930-1985) que contribuíram para a articulação do território nacional e a Amazônia: 
Quadro 1. Síntese das ações estatais afetas a articulação territorial e a Amazônia

\begin{tabular}{|c|c|c|}
\hline Fase & Governo & \\
\hline $\begin{array}{l}1930 \\
1945\end{array}$ & $\begin{array}{l}\text { Getulio Vargas } \\
\text { "Nova República" } \\
\text { "Estado Novo" }\end{array}$ & $\begin{array}{l}\text { Correio Aéreo Nacional e Departamento de Aviação Civil - } 1931 \\
\text { Constituição - } 1934 \\
\text { Serviços de Navegação da Amazônia e Adm. do Porto do Pará - } 1940 \\
\text { Criação de Territórios Federais em áreas fronteiriças - } 1943 \\
\text { Banco de Crédito da Borracha (BCB) - } 1944\end{array}$ \\
\hline $\begin{array}{l}1946 \\
1951 \\
1951 \\
1954\end{array}$ & Getulio Vargas & $\begin{array}{l}\text { Constituição - 1946; Escola Superior de Guerra (ESG) - } 1949 \\
\text { Banco de Crédito da Amazônia (BCA) - } 1950 \\
\text { Banco Nacional de Desenvolvimento Econômico (BNDE) - } 1952 \\
\text { Cooperação Militar Brasil/Estados Unidos - 1953; Amazônia Legal - } 1953 \\
\text { Superintendência P. de Valorização Econômica da Amazônia (SPVEA) - } \\
1953 \\
\text { Instituto Nacional de Pesquisas da Amazônia (INPA) - } 1954\end{array}$ \\
\hline $\begin{array}{l}1955 \\
1963\end{array}$ & $\begin{array}{c}\text { Juscelino } \\
\text { Kubitschek } \\
\text { "Anos Dourados" }\end{array}$ & $\begin{array}{l}\text { Plano de Metas de JK (1957-1960) - } 1956 \\
\text { Zona Franca de Manaus (ZFM) - } 1957 \text { (Porto Livre) } \\
\text { Rodovia BR-153 (Belém-Brasília) - } 1959 \\
\text { Rodovia BR-364 (Cuiabá-Porto Velho-Rio Branco) - } 1960 \\
\text { Construção de Brasília - 1960; Estatuto do Trabalhador Rural - } 1963\end{array}$ \\
\hline $\begin{array}{l}1964 \\
1985\end{array}$ & $\begin{array}{l}\text { Governos } \\
\text { Militares }\end{array}$ & $\begin{array}{l}\text { Estatuto da Terra - 1964; Reestruturação da Amazônia Legal - } 1966 \\
\text { Superintendência de Desenvolvimento da Amazônia (SUDAM) - } 1966 \\
\text { Banco da Amazônia S/A (BASA) - } 1966 \\
\text { Superintendência da Zona Franca de Manaus (SUFRAMA) - 1967 } \\
\text { Empresa de Navegação da Amazônia S.A. (ENASA) - 1967 } \\
\text { Plano Decenal de Desenvolvimento Econômico e Social (1967-1976) } \\
\text { Instituto Nacional de Colonização e Reforma Agrária (INCRA) - 1970 } \\
\text { Projeto RADAM - 1970; Programa de Integração Nacional (PIN) - } 1970 \\
\text { (PROTERRA - 1971; POLAMAZÔNIA - 1974 } \\
\text { I Plano Nacional de Desenvolvimento Econômico e Social - 1972-1974 } \\
\text { II Plano Nacional de Desenvolvimento Econômico e Social - 1975-1978 } \\
\text { Elaboração do Projeto Calha Norte - 1984 }\end{array}$ \\
\hline
\end{tabular}

Fonte: elaborado pelo Autor a partir de documentos oficiais

\section{A Panamazônia e o Tratado de Cooperação Amazônica}

Seguido ao término da II Guerra Mundial, interesses hegemônicos surgiram sobre a região amazônica, fazendo brotar uma questão geopolítica e o tema da Panamazônia (RIBEIRO, 2006). Os países sul-americanos, com vistas a defender seus interesses sobre a grande hileia, cuja bacia hidrográfica estende-se por sete países, conceberam em 1978, o Tratado de Cooperação Amazônica $^{28}$ (TCA). Mesmo tendo sido um acordo de cunho mais político do que territorial, no que se refere a porosidade territorial das fronteiras amazônicas, significou o revigoramento dos acordos assinados no início do século de livre navegação comercial no curso do rio Amazonas e demais rios amazônicos internacionais, garantiu a continuidades da navegação no Alto Solimões, na divisa entre Brasil, Colômbia e Peru.

\section{O significado da modernização conservadora à Amazônia e ao Alto Solimões}

Em consonância com o plano de integração nacional (PIN) foi criada a SUFRAMA ${ }^{29}$ (1967), incumbida de promover o Polo Industrial de Manaus (PIM). O Estado criou os fixos necessários (transportes, energia e política fiscal) para a ocupação pretendida e em pouco mais de uma década Manaus tornou-se metrópole regional. Sua população aumentou 80\% entre 1960-1970, e 206\% entre 1970-1980, devido à intensa imigração incentivada pelos programas de colonização e à expansão do mercado de trabalho, tornando-se a metrópole macrocefálica, que concentra $48 \%$ da população total do Estado do Amazonas nos dias atuais (IBGE, 1960, 1970, 1980, 1991 e 2010).

Para Becker e Egler (1994), o Brasil alcançou uma melhor posição graças às condições 
preexistentes: grande território, mercado interno e base industrial estabelecidos na fase anterior associado aos regimes autoritários. "O projeto geopolítico com o autoritarismo histórico resultou numa modernização conservadora [...] [a que foi] responsável imediata pela emergência do país como potência regional" (BECKER e EGLER, 1994, p. 124). Esse projeto geopolítico gestado desde 1930 acabou sendo gerido pelos militares.

O contexto político da época trouxe repercussões no Alto Solimões. Em 1955, vários municípios foram criados no Estado do Amazonas (MENEZES, 2009) e a partir 1968, os localizados na faixa de fronteira foram considerados Área de Segurança Nacional, onde se incluem Benjamim Constant. Tabatinga foi desmembrada de Benjamin Constant em 1981, sua sede foi inaugurada em $1^{\circ}$ de fevereiro de 1983, e somente foi reconhecida como Município autônomo pelo governo federal em 1985. "A presença institucional da Igreja e das Forças Armadas constituiu nessas cidades, a base para sua rede urbana que, dentre outras funções, desenvolveu um importante papel político na nacionalização do território" (MENEZES, 2009, p. 230). Por outro lado, esses núcleos urbanos sofreram a influência cultural da díade fronteiriça por viverem entrelaçadas historicamente aos países vizinhos desde antes das fronteiras. "Isoladas dos dois lados, pelos seus respectivos governos nacionais, as áreas de fronteira desenvolveram estratégias de sobrevivência, criando complementaridades, independentemente das macro-decisões nacionais, pela via dos fluxos de pessoas, bens e serviços" (FARRET, 1997, p. 108).

\section{As transformações modernizantes colombianas e ocupação da selva oriental}

Entre 1930 e 1946 houve um dinâmico crescimento do espaço urbano colombiano. Bogotá alcançou 250 mil habitantes e Medellín e Barranquilla deram sinais de importante atividade industrial. Seguiu-se um crescimento econômico da ordem de $5 \%$ ao ano, avançando a urbanização que atingiu 38\% em 1951, e propiciou a industrialização e criação de importantes empresas estatais no país, porém também foi crescente a desigualdade e injustiça social e territorial (GÓMEZ, 2005). As redes técnicas passaram a ser construídas de forma intensa a partir de 1950, sendo as carreteras quem trouxe maior fluidez territorial. Ao contrário da navegação fluvial, o transporte aéreo foi priorizado no âmbito nacional e internacional alcançando áreas remotas na Amazônia (GÓMEZ, 2005).

A partir de 1970 houve um declínio do PIB que atingiu seu mínimo nos anos 1990 concomitantemente às políticas de liberalização da economia e ao desmonte do Pacto Internacional do Café. Na mesma década houve uma expansão de cultivos ilícitos que alcançou $440 \%$ em área plantada e um aumento ascendente do desemprego. Nesse interregno Bogotá atingiu 6,3 milhões de habitantes, houve a exploração petrolífera no sul que estimulou o crescimento da população ao largo do piemonte da cordilheira oriental, a continuação da colonização da Amazônia e o auge dos cultivos ilícitos (GÓMEZ, 2005).

Fatores relacionados ao esgotamento da fronteira agrícola, à pressão demográfica, às tensões sociais e a violência política dos anos 1940 levaram ao processo da colonização $\operatorname{armada}^{30}$. O fenômeno desencadeou no período 1951-1960, processos migratórios e entre eles um fluxo em direção ao oriente e a Amazônia colombiana, porém este não atingindo o Trapézio Amazônico (VARGAS, 1999). No ínterim 1942-1944, ante a necessidade de borracha dos Aliados da Segunda Guerra, se instalou na Amazônia a Rubber Development Corporation, empresa norte-americana responsável pela comercialização da borracha com mão-de-obra local. Em $1945^{31}$ a Rubber se retirou deixando acampamentos e pistas de pouso que originaram povoados (DOMÍNGUEZ, 1985, 1990). Nesses se instalaram as Repúblicas Independentes originárias da colonização armada, que por onde passaram as Columnas em Marcha deixavam germes populacionais. Em 1960 o governo central combateu os insurgentes, introduzindo o Exército e instalando colônias militares, recuperando o seu controle. Paradoxalmente, do desmantelamento desses núcleos nasceram as FARC ${ }^{32}$ em 1965 (VARGAS, 1999). É nesse contexto, que renasce Leticia, tal como Tabatinga, resultado de uma verticalidade estatal de caráter militar ${ }^{33}$ para assegurar a posse e $o$ controle territorial na tríplice fronteira e o acesso à navegação ao vale do rio Amazonas. 


\section{O narcotráfico e a ocupação da Amazônia colombiana}

Até final da década de 1960 os cultivos ilícitos na Colômbia eram pouco conhecidos (GÓMEZ, 2005). No final dos anos 1970 os cultivos de coca na fronteira Equador-Peru se alastraram ao longo do rio Putumayo (fronteira colombiana) promovendo uma imigração e colonização (VARGAS, 1999). Os produtos químicos indispensáveis ao processamento da pasta e o transporte foram encontrados no subespaço Leticia-Tabatinga, dada a saída fluvial pelo rio Solimões-Amazonas em direção a Manaus e ao mercado internacional. Assim o subespaço tornou-se corredor da droga possibilitando crescer o Cartel de Leticia ${ }^{34}$ (1979).

A economia da droga provocou a "colonização do narcotráfico" nos anos 1970 (VARGAS, 1999, p. 78), e dominou a economia regional entre 1977-1986, fomentando o crescimento de Leticia e Tabatinga, onde o dinheiro da droga era lavado pelos traficantes (STEIMAN, 2002). A população de Leticia, entre 1973-1985 aumentou 191\%. O auge do tráfico ocorreu em 1986 e também os assassinatos por dívidas que perduram até hoje. Dada a debilidade das instituições, obtido o poder econômico, não demorou o poder político, tal como afirma Machado (1996), as atividades ilícitas podem gerar efeitos geográficos, migratórios e "modificações nas estruturas de poder" (p. 27). Raffestin (1980) "Aqueles que estão em condições de exercer o poder criam o território organizado" (p. 197).

\section{AS ÚLTIMAS TRÊS DÉCADAS (1980-2010): INTEGRAÇÃO, FLUIDEZ E POROSIDADE}

A segunda metade da década de 1980 acenava o final da Guerra Fria e a América Latina adentrava numa fase de democratização onde vários países romperam anos de ditaduras. $\mathrm{O}$ Brasil, nesse contexto, promulgou sua última Constituição em 1988 e a Colômbia em 1991. Essas Cartas Magnas representaram uma importante guinada política para ambos os países. No caso brasileiro, a divisão político administrativa sofreu alterações e centenas de municípios foram criados/emancipados, situação que não acontecia a mais de 20 anos (CATAIA, 2001). Nesse movimento, em 23 de outubro de 1985, Tabatinga foi reconhecida como município autônomo após quatro anos de contendas políticas, e Leticia, por sua vez, em 1991, foi elevada a Capital del Departamento de Amazonas.

A partir de 1990, Tabatinga e Leticia passaram a receber uma série de investimentos correlatos à institucionalização e modernização os quais elevaram o subespaço a um patamar superior. Infraestruturas e instituições de nível federal foram instaladas abrindo novas possibilidades de fluxos e promovendo um incremento da conectividade territorial, passando o subespaço a estabelecer links para fora de sua hierarquia urbana imediata e a se relacionar com lugares distantes, dando sinais de inserção na economia nacional e mundial. A camada modernizante trouxe uma nova realidade social e econômica ao lugar.

A partir da elevação de Leticia à Capital, e principalmente após 2000 (Plan Colombia), a Colômbia instalou um aparato militares del Ejército e de la Armada em Leticia e passou reprimir o narcotráfico de forma intensa, consolidando a institucionalização do território leticiano e o controle da ampla região de selva adjacente. Em 1995, a Colômbia criou as Unidades Especiais de Desenvolvimento Fronteiriço ${ }^{35}$ (UEDF), cujo regime jurídico-territorial aplicou-se a Leticia em 1999, e que associado aos subsídios que já gozavam as companhias aéreas colombinas que operavam em Leticia, abriu um novo leque de fluxos comerciais com o interior de seu país e com o exterior. Do lado brasileiro, Tabatinga havia se tornado Área de Livre Comércio dez anos antes que Leticia (foi a primeira a ser instituída no Brasil em 1989), e goza desde então de isenção de impostos para importação e exportação, no entanto, Leticia é quem melhor faz uso desse diferencial até hoje.

A organização economia de Leticia evoluiu para um novo cenário. Deixou de depender exclusivamente dos proventos do funcionalismo públicos e incrementou o comércio local com o 
Brasil e o Peru em função do alargamento dos poros jurídicos fronteiriços pela via da importação e exportação e da melhoria das condições de transporte aéreo e fluvial.

No Brasil, Tabatinga também experimentou um aporte institucional significativo no período, sobretudo após 2000 quando uma série de instituições ligadas à saúde, educação, segurança e justiça foram instaladas e/ou revigoradas, além de receber investimentos destinados a equipamentos urbanos, pavimentação, saneamento, etc. A elevação das condições físicas, institucionais e jurídicas favoreceu a intensificação dos fluxos comerciais com Letícia e teve replexos positivos na economia local e na dinâmica populacional. Hoje ambas as cidades, vivem uma espécie de simbiose: economicamente são complementares, suas populações compartilham do mesmo território e entrelaçam-se social e culturalmente. Enfim percebe-se que houve uma melhoria das condições de vida da população e o subespaço atingiu um novo patamar de produtividade territorial e valor geopolítico.

\section{As fronteiras e a Política de Defesa Nacional brasileira no início do século XXI}

A legislação de defesa brasileira foi reformulada em 2005 quando foi instituída a atual Política de Defesa Nacional ${ }^{36}$ (PDN). Esta apresenta uma nova abordagem e postura diante de assuntos relativos à economia, integração nacional e política interna e externa, especialmente na América Latina. Regulamentando a PDN foi aprovada em 2008 a Estratégia Nacional de Defesa ${ }^{37}$ (END), cuja tese central conjuga defesa e desenvolvimento: "Projeto forte de defesa favorece projeto forte de desenvolvimento". As diretrizes da Estratégia dão prioridade à região amazônica, à faixa de fronteira e ao aprofundamento das relações com os países limítrofes. (BRASIL, 2008, p. 9-14). Conceitualmente, parece-nos um novo paradigma na medida em que a PDN volta-se à transparência da gestão e a inclusão da participação da sociedade em sua execução. Nessa direção, em 2010, foi criado o Livro Branco de Defesa Nacional (LBDN), como veículo de diálogo entre o Estado brasileiro, a sociedade nacional e internacional. Documento inédito no país, criado nos moldes das democracias contemporâneas voltado a dar transparência à política de defesa.

Como instrumentos executivos, o Programa Calha Norte (PCN) foi fortalecido para a região amazônica (BRASIL, 2008, p.45) juntamente com o Programa de Desenvolvimento da Faixa de Fronteira (PDFF) para toda a região fronteiriça. Ambos, associados ao estreitamento da cooperação com os países vizinhos compôs a estratégia de desenvolvimento.

\section{O Programa Calha Norte (2004): as novas vertentes e a ampliação do escopo}

O Programa Calha Norte, consolidado há 34 anos, tem por objetivo promover a ocupação e desenvolvimento da região norte. Nasceu como projeto em 1985 e passou a Programa em 2004. Quando foi concebido tinha a Segurança Nacional como principal vertente (RIBEIRO, 2006), desde então teve sua aérea territorial ampliada e assumiu além da "vertente militar" a "civil", que se refere ao "Apoio às Ações de Governo na Promoção do Desenvolvimento Regional" (BRASIL, 2007, p. 2). A "vertente civil" voltada ao desenvolvimento local atua em sete áreas: infraestrutura social; transportes; econômica; esportes; educação, saúde, segurança e defesa. O PCN é o principal responsável pela instalação dos sistemas de engenharia básicos nas áreas mais inóspitas e distantes da Amazônia brasileira através das Forças Armadas e, recentemente ${ }^{38}$ recebeu nova normatização e passou a ser coordenado pelo Departamento do Programa Calha Norte. Ao redor desses pontos isolados tem se desenvolvido núcleos urbanos e contribuindo assim para o desenvolvimento social e a integração nacional. O Programa continua sendo em grande parte responsável pela presença do Estado brasileiro na Amazônia setentrional, tanto nas ações voltadas à infraestrutura como nas sociais de atendimento às tribos indígenas e às comunidades ribeirinhas (BECKER, 2009).

O Programa de Desenvolvimento da Faixa de Fronteira (PDFF-2008) abre os poros da fronteira brasileira

O segundo instrumento de ação alinhado à END voltado à faixa de fronteira que inclui o arco 
norte da Amazônia é o PDFF ${ }^{39}$. Relançado em 2008, o Programa concebe uma nova "mentalidade no tocante às fronteiras, que não podem mais ser entendidas como áreas longínquas e isoladas, e sim como uma região com a singularidade de estimular processos de desenvolvimento e integração regional". Entende que "As faixas contíguas dos países fronteiriços apresentam vantagens comparativas para provocar o fortalecimento regional, a partir de características políticas e propósitos comuns" (BRASIL, 2008, p. 2). Visa promover o desenvolvimento da Faixa de Fronteira por meio da implantação de uma estruturação física, social e produtiva, com ênfase no aproveitamento das potencialidades econômicas locais e o estreitamento da cooperação com os 10 países vizinhos da América do Sul. Politicamente o Programa encarna uma estratégia oposta ao padrão de intervenção observado nas últimas décadas, reunido o respeito à diversidade regional; associação da soberania à perspectiva de desenvolvimento e integração da América do Sul; e fortalecimento das condições de cidadania das populações locais (BRASIL, 2008), reconhecendo assim, "o caráter estratégico do desenvolvimento dessa região e a enorme dívida social a ser resgatada" (OLIVEIRA, 2005, p. 7). O desenvolvimento das cidades gêmeas é prioridade, entendidas estas como oportunidades de fortalecimento de integração social e institucional em bases supranacionais, com destaque para Tabatinga-Letícia. No sentido de coordenar as ações do PDFF, em 2010 foi instituída a Comissão Permanente para o Desenvolvimento e a Integração da Faixa de Fronteira (CDIF) composta por cerca de vinte representantes e estabelecendo sua secretaria executiva como sendo a Secretaria de Programas Regionais do Ministério da Integração Nacional, infelizmente, revogado pelo Dec. $\mathrm{n}^{\circ}$ 9.961/2019.

\section{Comissão de Integração Brasil-Colômbia e os Comitês de Fronteira (2008)}

A Comissão de Integração Brasil-Colômbia ${ }^{40}$ e os Comitês de Fronteira ${ }^{41}$ foram revigorados a partir do relançamento do PDFF. Entre os últimos acordos realizados ou em desenvolvimento, podemos destacar: o ensino de português e espanhol na fronteira (2005); a Zona de Regime Especial Fronteiriço para as localidades de Tabatinga e Leticia (2008), que visa incrementar os fluxos comerciais fronteiriços pela via da flexibilização aduaneira, entre outras iniciativas relacionadas à saúde, educação e segurança.

As ações desenvolvidas a nível dessa Comissão de Integração, contudo, configuram uma "integração por cima", realizada entre as instâncias políticas da esfera federal dos países - viceconsulados. A sociedade local "esfera do cotidiano", no entanto, fica à margem das discussões realizadas nos gabinetes "esfera superior", situação que leva a soluções teóricas incompatíveis com a práxis cotidiana da população fronteiriça. Seria pertinente que as discussões fossem colegiadas de fato, com a participação das autoridades locais, representantes comunitários e universidades, a fim de atingir soluções mais próximas das necessidades imediatas da população e dentro de prazos menos extensos.

\section{CONSIDERAÇÕES FINAIS}

O estudo permitiu verificar que o arranjo social e espacial das cidades gêmeas foi condicionado pelo modelo de colonização, modernizações impostas e, sobretudo, por questões geopolíticas clássicas e contemporâneas e estes fatores atuaram de forma diferenciada em cada um dos períodos históricos delimitados.

Cidades diferentes no que se refere à formação socioespacial correspondente ao país a que pertencem, porém similares quanto ao processo de ocupação e significação econômica do território baseado na exploração da borracha, e, sobretudo, no que tange às suas relações sóciohistóricas de nascença indígena anteriores à existência da própria fronteira.

As mudanças verificadas nas últimas três décadas vêm provocando modificações na dinâmica territorial, econômica e social do subespaço e na vida de relação da população fronteiriça de forma acelerada. Nesse contexto, a atual política de defesa brasileira orientada para a 
aproximação dos países sul-americanos trouxe uma resignificação das fronteiras lhes concedendo maior porosidade e fluidez e ao mesmo tempo reforço político aos países amazônicos no sentido da defesa estratégica conjunta da grande floresta amazônica.

Esse conjunto de fatores parece-nos explicar a centralidade que vem se desenvolvendo em torno do subespaço, no entanto, resta-nos saber, quão sólidos e/ou sensíveis são esses fatores diante da conjuntura política e econômica dos países envolvidos, atrelados que estão às oscilações do mundo globalizado.

\section{REFERÊNCIAS}

ANDRADE, Manuel C. Geopolítica do Brasil. 3.ed. Campinas: Papirus, 2007 [2001].

BECKER, Bertha K. Amazônia. 3.ed. Rio de Janeiro: Ática, 1994 [1990].

BECKER, Bertha K. Amazônia: geopolítica na virada do III milênio. 3.ed. Rio de Janeiro: Garamond, 2009 [2004].

BECKER, Bertha K. e EGLER, Claudio A. G. Brasil: uma nova potência regional na economia-mundo. 2. ed. Rio de Janeiro: Bertrand Brasil, 1994 [1992].

BRASIL. Ministério da Defesa. Diretrizes Estratégicas para o Programa Calha Norte. Portaria Normativa $\mathrm{n}^{\circ} 1.185$, de 13/09/2007, 2007.

BRASIL. Ministério da Integração Nacional. Programa de Promoção do Desenvolvimento da Faixa de Fronteira - PDFF. Brasília, 2008.

BRASIL. Presidência da República. Decreto $\mathrm{n}^{\circ}$ 5.484, de 30 de junho de 2005. Política de Defesa Nacional, 2011. Disponível em: <https://defesa.gov.br> Acesso em: julho de 2011.

CATAIA, Márcio Antonio. Território nacional e fronteiras internas: a fragmentação do território brasileiro. Tese de Doutorado. Departamentos de Geografia, FFLCH, USP, 2001.

COLOMBIA. Ministerio de Defensa Nacional. Conflicto Amazónico 1932-1934. Bogotá: Villegas Editores, 1994.

COLOMBIA. Ministerio de Relaciones Exteriores. Arreglo de limites entre la Republica de Colombia y la Republica de Perú. Bogotá: Imprenta Nacional de Colombia, 1979.

COLOMBIA. Ministerio de Relaciones Exteriores. (1982) Arreglo de limites entre la Republica de Colombia y los Estados Unidos de Brasil. Bogotá: Imprenta Nacional de Colombia.

COLOMBIA. Ministerio de Relaciones Exteriores. Ley n ${ }^{\circ} 160$. Convenio de Cooperación Aduanera entre la República de Colombia y la Republica Peruana. Bogotá, 1938.

CORRÊA, Roberto Lobato. A organização urbana. In: Geografia do Brasil, Região Norte, Rio de Janeiro: IBGE, 1989. Vol. 3, 255-71.

COSTA, Wanderley M. da. O Estado e as políticas territoriais no Brasil. 6.ed. São Paulo: Contexto, 1997, [1988].

COUTO E SILVA, Golbery de. Conjuntura Política Nacional: o Poder Executivo \& Geopolítica do Brasil. 3.ed. XX: Rio de Janeiro: Jose Olympio, 1981.

DOMÍNGUEZ, Camilo Augusto Gómez. La economía extractiva en la Amazonia colombiana: 18501930. Bogotá: Banco Popular, 1990.

DOMÍNGUEZ, Camilo Augusto Gómez. Amazonia colombiana: visión general. Bogotá: Banco Popular, 1985.

FARRET, Ricardo. Especificidades das áreas urbanas de fronteira. In: CASTELLO, I. R. et ali (Org.). Fronteiras na América Latina. Porto Alegre: Editora da UFRGS/FEE, 1997.

FURTADO, Celso. Formação econômica do Brasil. 11.ed. São Paulo: Companhia Editora Nacional, 1971, [1959]. 
GADELHA, Regina Maria. Conquista e ocupação da Amazônia: fronteira norte do Brasil. Revista Eletrônica do Instituto de Estudos Avançados, 2002. Vol.16, Nr.45. Disponível em: http://www.scielo.br/pdf/ea/ v16n45/v16n45a05.pdf Acesso em: 21 de julho de 2011.

GÓMEZ, Gustavo M. Globalização e construção do território colombiano. In: Continente em chamas. SILVEIRA, M. Laura. (org.). Civilização Brasileira, Rio de Janeiro, 2005. p. 243-281.

HUERTAS, Daniel Monteiro. Da fachada atlântica ao âmago da hiléia: integração nacional e fluidez territorial no processo de expansão da fronteira agrícola. Dissertação de Mestrado. Depto. de Geografia, FFLCH, USP, 2007.

MACHADO, Lia O. Mitos e realidades da Amazônia brasileira no contexto geopolítico internacional (1540-1912). Tese de Doutorado. DGH. Universidade de Barcelona, 1989.

MACHADO, Lia O. O comércio ilícito de drogas e a geografia da integração financeira: uma simbiose? In: CASTRO, I. E. et all. (org), Brasil. Questões atuais da reorganização do território, Rio de Janeiro, Bertrand Brasil, 1996. p. 15-64.

MACHADO, Lia O. Estado, territorialidades, redes. Cidades gêmeas na zona de fronteira sul-americana. In: SILVEIRA, M. L. (org.). Continente em chamas. Globalização e território na América Latina. C. Brasileira, Rio de Janeiro, 2005.

MENEZES, Maria L. P. Pequenas cidades em faixa de fronteira na Amazônia: o caso de Tabatinga e Benjamin Constant. In: OLIVEIRA, José Aldemir. (org.). Cidades Brasileiras: territorialidades, sustentabilidade e demandas sociais. Vol. 1. Manaus: EDUA, 2009.

MORAES, Antonio Carlos Robert. Bases da formação territorial do Brasil: o território colonial brasileiro no "longo" século XVI. São Paulo: Hucitec, 2000.

NOGUEIRA, Ricardo J. B. Território de Fronteira: Brasil/Colômbia. In: VIII Congresso Luso-AfroBrasileiro de Ciências Sociais. Coimbra/Portugal, 2004. VIII CES.

NOGUEIRA, Ricardo J. B. Tabatinga: uma cidade na fronteira na Amazônia. In: CASTRO, Edna. (org.). Cidades na Floresta. São Paulo: Annablume, 2008.

OLIVEIRA, José Aldemir de. Trilhas e atalhos: as cidades amazônicas no final do século XX. In. ALVES, Claudia Lima Esteves. Formação do Espaço Amazônico e relações fronteiriças. Boa Vista: CCSG-UFRR, 1998.

OLIVEIRA, Tito Carlos Machado de. (org.). Território sem limites: estudos sobre fronteiras. Campo Grande: Ed. UFSM, 2005.

RAFFESTIN, Claude. Por uma geografia do poder. São Paulo: Ática. Paris, 1993, [1980].

REZENDE, Tadeu Valdir F. A conquista e a ocupação da Amazônia brasileira no período colonial: a definição das fronteiras. Tese de Doutorado. DHE, FFLCH, USP, 2006.

RIBEIRO, Nelson de Figueiredo. A questão geopolítica da Amazônia: da soberania difusa a soberania restrita. Belém: Editora Universitária da UFPA, 2006.

RODRIGUES, Lysias A. Geopolítica do Brasil. Rio de Janeiro: Biblioteca Militar, 1947.

SANTOS, Milton. Da Totalidade ao Lugar. São Paulo: EDUSP, 2008a, [1979].

SANTOS, Milton. O espaço dividido: os dois circuitos da economia urbana dos países subdesenvolvidos. 2.ed. São Paulo: EDUSP, 2008b, [1979].

STEIMAN, Rebeca. A geografia das cidades de fronteira: um estudo de caso de Tabatinga (Brasil) e Letícia (Colômbia). Dissertação de Mestrado. D. Geografia, UFRJ, 2002.

TRAVASSOS, Mário. Projeção continental do Brasil. 4.ed. Coleção Brasiliana. Série 5a. Vol. 50. Biblioteca Pedagógica Brasileira. Rio de Janeiro: Cia Editora Nacional, 1947.

VARGAS, Gloria Maria. Território e poder: a formação socioespacial colombiana. Tese de Doutorado. Departamentos de Geografia, FFLCH, USP, 1999. 
ZÁRATE, B. Carlos. Espacios urbanos transfronterizos en la historia de la Amazonia. In: ZÁRATE, B. Carlos et all (org.). Espacios urbanos y sociedades transfronterizas en la amazonia. Bogotá: Universidad Nacional de Colombia (Cátedra Jorge Eliecer Gaitán), 2012.

ACUÑA, J. Enrique. Leticia, la transformación urbana de una ciudad amazónica y fronteriza. In: ZÁRATE, B. Carlos et all (org.). Espacios urbanos y sociedades transfronterizas en la amazonia. Bogotá: Universidad Nacional de Colombia (Cátedra Jorge Eliecer Gaitán), 2012.

\footnotetext{
${ }^{1}$ Instituto Brasileiro de Geografia e Estatística, estimativa da população, 2019.

2 Departamento Administrativo Nacional de Estadística, Colômbia, dados de 2018

${ }^{3}$ As Coroas de Portugal e Espanha estiveram unidas sob um único governo entre 1580 e 1640 constituindo a União Ibérica e formando o maior império territorial de todos os tempos (REZENDE, 2006)

${ }^{4}$ Instrumento político e econômico usado para subjugar os índios. O índio ficou obrigado a pagar um tributo, fosse em espécie ou em trabalho ao encomendeiro em troca de proteção e evangelização (VARGAS, 1999)

${ }^{5}$ Localidade peruana situada na província de Loreto utilizada como base para incursões e conquistas pela floresta nacional até 1640 (fim da União Ibérica), quando os espanhóis diminuíram sua atuação devido às invasões portuguesas.

${ }^{6}$ Sebastião José de Carvalho e Melo, Secretário de Negócios Estrangeiros e da Guerra nomeado por D. José I (1750). Absolutista, anticlericalismo e tinha o mercantilismo como modelo econômico (RIBEIRO, 2006).

${ }^{7}$ Coletores de quina, importante planta medicinal com valor comercial para exportação.

${ }^{8}$ Coletores de látex das seringueiras para a produção da borracha.

${ }^{9}$ Cauchería peruana de Julio César Aranha que ocupava uma imensa área à margem esquerda do rio Putumayo em território colombiano. O empreendimento desalojou colonos colombianos, usava mão-de-obra indígena e escrava. Em 1912 passou a dominar o comércio de borracha na região, ter força política junto ao governo central de seu país e se afiançou ao capital inglês formando a Peruvian Amazonic Company Limited.

${ }^{10} \mathrm{O}$ Estado promoveu a ocupação de áreas de fronteira incentivando a formação de colônias agrícolas.

${ }^{11}$ Denominação dada ao intenso e rápido ciclo econômico advindo do comércio de exportação da borracha.

${ }^{12} \mathrm{Em} 1852$ foi concedida exclusividade de navegação no rio Amazonas à Companhia de Navegação e Comércio do Amazonas, empresa do Barão do Mauá, condicionado à fundação de 60 colônias ao longo de rios da região.

${ }^{13}$ Modelo creditício concebido para o custeio da safra da borracha que era capilarizado até as mais distantes regiões. Institucionalizou a dependência total do seringueiro e a escravidão por dívida.

${ }^{14}$ Foi igualmente a borracha que fez Iquitos (Peru) desenvolver-se de forma surpreendente em meio a selva peruana, sendo hoje uma cidade com mais de 400 mil hab. e seu porto fluvial é o mais importante do país.

15 Também denominado de Tratado Vásquez Cobo-Martins. Documento que definiu a fronteira noroeste brasileira entre Brasil e Colômbia como sendo o contorno da região da "Cabeça do Cachorro", desde a pedra de Cucuí até a confluência dos rios Apaporis e Caquetá (Colômbia), cuja extensão é o rio Japurá (Brasil), de onde seguiria uma linha geodésica até Tabatinga (COLOMBIA, 1982).

${ }^{16}$ Trapézio

17 Major-Brigadeiro-do-Ar. Fez parte do Correio Aéreo Nacional, profundo conhecedor das ligações aéreas do Centro-Oeste e Norte do Brasil, além da divisão territorial defendia a mudança de localização da capital.

${ }^{18}$ Criados pelo Decreto-lei no 5.812, de 13 de setembro de 1943, durante o governo Vargas, os Territórios Federais do Amapá, Rio Branco, Guaporé, Ponta Porã e Iguaçu, tinham o objetivo geopolítico de tornar mais forte a ação do poder público federal sobre as áreas que haviam sido objeto de litígio fronteiriço.

${ }_{19}$ Contingente de brasileiros que foram mobilizados para a Amazônia a fim de extrair borracha para suprir as necessidades do esforço de guerra norte-americano/brasileiro (1943/45).

${ }^{20}$ Serviço de Navegação da Amazônia e de Administração do Porto do Pará (1940), substituída pela Empresa de Navegação da Amazônia S.A. (ENASA) em 1967 e a Companhia Docas do Pará (CDP).

21 Área que abrange nove estados brasileiros pertencentes à Bacia amazônica. Composta da totalidade dos estados do Acre, Amapá, Amazonas, Pará, Rondônia, Roraima e Tocantins, parte dos Estados do Maranhão e Mato Grosso, e cinco municípios de Goiás, totalizando 761 municípios (IBGE, 2005), perfazendo uma superfície de aproximadamente 5,2 milhões de $\mathrm{km}^{2}$, correspondendo a cerca de $61 \%$ do território brasileiro.

22 Documento que passou a orientar o poder público quanto aos projetos para a região. Incluía o zoneamento econômico e social e definia grandes estratégias de curto, médio e longo prazo para a Amazônia.

${ }^{23}$ Superintendência de Desenvolvimento da Amazônia.

${ }^{24}$ Banco de Crédito da Amazônia foi transformado no Banco da Amazônia S.A.

${ }^{25}$ Ministério do Interior, criado em 1967.

${ }^{26}$ I Plano Nacional de Desenvolvimento Econômico e Social.

${ }^{27}$ Plano de Integração Nacional.

${ }^{28}$ Assinado por Bolívia, Brasil, Colômbia, Equador, Guiana, Peru, Suriname e Venezuela.

${ }^{29}$ Superintendência da Zona Franca de Manaus, 1967.
} 


\footnotetext{
${ }^{30}$ Movimento camponês onde colonos armados ocuparam terras, amparado por grupos liberais e comunistas entre 1955-1965, constituindo o que se chamou de Repúblicas Independentes (VARGAS, 1999, p. 68-72).

${ }^{31}$ Similar ao que ocorreu na Amazônia Brasileira por meio dos "Soldados da Borracha".

${ }^{32}$ Forças Armadas Revolucionárias da Colômbia (FARC).

${ }^{33}$ Instalação da Colônia Militar de Tabatinga (1967) e da Base Naval da Armada Nacional da Colômbia, na década de 1930 logo após o final do Conflito de Letícia.

${ }^{34}$ Cartel que atuou na região sul da selva oriental colombiana e dominou Leticia e Tabatinga, sendo considerado o terceiro maior da Colômbia, foi dissolvido no final da década de 1980. (STEIMAN, 2002).

35 Áreas especiais de fronteira com legislação específica de livre comércio, criadas através da Lei no 191, "Ley de Fronteras", de 1995, com vistas ao desenvolvimento regional.

${ }^{36}$ Através do Decreto n ${ }^{\circ} 5.484$, de 30 de junho de 2005.

${ }^{37}$ Por meio do Decreto ${ }^{\circ}$ 6.703, de 18 de dezembro de 2008.

${ }^{38}$ Portaria Normativa ${ }^{\circ} 115$, de 29 de dezembro de 2019, do Ministério da Defesa.

39 De 1999 a 2007 o PDFF foi encargo do Ministério da Integração Nacional e caracterizou-se por projetos desarticulados e fragmentados (COSTA e GADELHA, 2005). Em 2008 foi reformulado com base na Proposta de Reestruturação do Programa de Desenvolvimento da Faixa de Fronteira (2005), desenvolvido pelo Grupo RETIS da UFRJ, coordenado pela Prof. Lia O. Machado e Rogério Haesbaert, da UFF (BRASIL, 2008, p. 14).

${ }^{40}$ Comissão instituída em 1993. Mantém reuniões anuais em nível de Vice-Chancelarias e representa o principal foro de discussão dos temas fronteiriços entre os dois países. Cf. Ministério das Relações Exteriores do Brasil, Depto. da América do Sul II, 2011.

${ }^{41}$ Organizados pelo Ministério das Relações Exteriores, destina-se a identificar as necessidades locais e ser os “ouvidos" federais às demandas locais e a dar respaldo político à voz das sociedades fronteiriças.
} 